\title{
SENSITIZATION TO TUBERCULIN INDUCED BY LEPROMIN
}

\author{
Jose M. M. Fernandez, M.D., and Luis Cabanillas, M.D. \\ with the technical assistance of \\ Perla Zampettini
}

\section{INFLUENCE OF LePROSy ON THE TUberCulin REACTION}

The influence of leprosy on the lepromin reaction has been demonstrated and confirmed in many investigations. On the other hand, the influence of $M$. leprae on the tuberculin reaction has not awakened much interest, and the literature on this subject is by no means abundant. Wade ${ }^{(1)}$ has discussed it in a well documented paper, and one of us (J.M.F.) presented his personal experience and views on the occasion of the Third Argentine Congress on Tuberculosis(2).

Convit and his associates(3) admit that infection by leprosy may interfere in the sensitization to tuberculin. In 1952 they observed persons in contact with lepers in a rural district in Venezuela and found only 8 per cent tuberculin positive cases in lepromin negative individuals and 46.6 per cent in lepromin positive subjects. In a recent paper Convit(4) confirms his former findings, stating that there are 3 per cent Mantoux positive (D.P.P. $5 \mathrm{U}$ ) in lepromin negative, and 45 per cent in lepromin positive individuals.

Lowe and McNulty(5) have studied immuno-allergic relations between leprosy and tuberculosis in natives of Nigeria. Their results, as they themselves point out, are contradictory, because although in anergics to lepromin the percentage of tuberculin positives (59.4 per cent) was lower than in the healthy population (75.2 per cent), it was slightly above that found in cases of tuberculoid leprosy (55 per cent).

Hadler and $\mathrm{Zitti}(6)$ have reported recently the results of their investigations on the influence of $M$. leprae, $M$. lepraemurium and $M$. tuberculosis on sensitiveness to tuberculin in guinea pigs. They have shown that $M$. leprae and $M$. lepraemurium sensitize guinea pigs to tuberculin, with maximum intensity at thirty and sixty days respectively; later sensitiveness declines and disappears. Tuberculin hypersensitiveness induced in guinea pigs by $M$. lepraemurium is the same as that induced by $\mathrm{BCG}$. They conclude that tuberculin hypersensitiveness in guinea pigs inoculated with $M$. leprae and $M$. lepraemurium depends on two factors: (a) the capacity of the macrophages of destroying these bacilli, lysis of which provokes tissue reaction and hypersensitiveness; and (b) the similarity in the chemical structure of some of the antigenic fractions of $M$. leprae and $M$. lepraemurium, which is responsible for cosensitization.

\section{MATERIAL AND MethodS}

\section{Personal EXPERIENCE}

As the results of previous investigations, carried out by one of the authors of this paper, on the influence of lepromin on tuberculin reaction, were not conclusive, it was decided to repeat the tests, increasing the number of cases. 
Observations were made in a group of eighteen children, aged 3 months to 8 years, lodged in a home, and who had had no known contact with lepers; they were Mantoux negative at I : Io.

Crude tuberculin, prepared at the Malbran Institute of the National Ministry of Health, was used in concentrations of I : I,000, I : I00, and I : Io. Two types of lepromin, both prepared by Dr. A. Serial and A. R. Mercau, were used: (a) bacillary, obtained by chloroform extraction according to Dharmendra's method; (b) whole, prepared by the Mitsuda-Hayashi method.

A single intradermal injection, in doses of 0.1 to 0.2 c.c., in the right scapular region, was given in four cases; this was repeated at 48-hour intervals, once in twelve cases and twice in two cases. Sensitiveness to tuberculin (Mantoux I : Io) was tested from the third week after the injection of lepromin, and periodically after that. However, for reasons outside our control, this could not be done at regular intervals in all cases as had been planned in order to determine exactly at what moment the Mantoux reaction became positive.

Cases classified as tuberculin negative were given a Mantoux test for at least three months following the lepromin injection, except in one instance in which the child was withdrawn before this period was up. The Mantoux reaction was read at 24 and 48 hours, the latter being considered as the final result. It was taken as positive when an infiltrated erythematous halo of not less than Io $\mathrm{mm}$. diameter was observed.

\section{Results}

Results are given in the Table. In 8 (44.4 per cent) of the I8 cases the negative Mantoux became positive after the lepromin injection. The majority of the cases became positive between the sixth and seventh week after the lepromin injection; one became positive in 20 days, and in another, which could not be tested regularly, a positive Mantoux was seen only after I30 days.

Positive Mantoux reactions following lepromin injection are similar in appearance and evolution to those induced by BCG vaccination. Reactions of erythematous or erythemato-violacious type, with discrete infiltration, predominated. Frequently erythema was more marked at 24 than at 48 hours. In all cases, except Nos. I and 2, positivity was slight. In several cases an erythematous halo without infiltration was observed; there were considered as negative.

In those cases in which it was possible to follow the course the course of tuberculin allergy it was found to be transitory, since 
after a few weeks the reactions. became negative.

To illustrate the findings notes corresponding to some of the cases included in the Table are given here:-

No. 1

Maria P., aged 2 years 6 months. Routine clinical and X-ray examination: negative.

8.II.I95I: Mantoux I : ro negative (-).

27.II.I95I: 0.2 c.c. whole lepromin intradermally.

30.II.195I: do.

27.12.195I: Mantoux I : ro, negative $(-)$.

Io. 4.1952: Mantoux -I : Io positive $(+)$.

21. 4.I952: Mantoux I : Io positive $(+)$. In the scapular region two scars corresponding to the Mitsuda reaction $(++)$ were observed.

21. 5.1952: Mantoux I : io positive $(+)$. Clinical and X-ray examination, normal.

21. 6.1952: Mantoux I : Io negative (-).

5. 7.1952: Mantoux I : Io negative (-).

Note: The Mantoux may have become positive before April, 1952; the child left the home in December and did not return till April.

No. 2

Stella A., I year old. Routine clinical and X-ray examination, negative.

9. 3.1952: Mantoux I : Io negative (-).

I0. 4.1952: o.2 c.c. whole lepromin intradermally.

12. 4.1952: do.

22. 5.1952: Mitsuda positive $(++)$. Mantoux I: Io negative $(-)$.

5. 6.I952: Mantoux I : Io negative $(-)$.

21. 6.1952: do.

5. 7.1952: do.

22. 7.1952: do. Erythematous halo without infiltration.

No. 4

Rodolfo S., 6 years old. Routine clinical and X-ray examination, negative.

8.II.195I: Mantoux I : ro negative.

24.II.195I: 0.2 c.c. whole lepromin intradermally.

27.II.I95I: do.

30.II.I95I: do.

II.I2.I95I: Mitsuda positive $(++)$. Mantoux I : Io negative (-).

4. I.I952: Mantoux I : Io negative (-).

25. 3.1952: do.

17. 4.1952: do.

5. 6.1952: do.

No. 17

Mario P., Argentine. Routine clinical and X-ray examination, negative.

8.II.I953: Mantoux I : ro negative (-).

30.II.1953: O.I bacillary lepromin intradermic.

18.I2.I953: Mitsuda positive $(++)$. Mantoux I : Io negative $(-)$.

12. I.r954: Mantoux I : Io positive ( + ).

I7. 3.I954: Mantoux I : Io doubtful ( \pm ). Erythematous halo without infiltration.

\section{Discussion}

Before discussing the results it is necessary to acknowledge several deficiences in this investigation. The weakest point is the insufficient control of the course of tuberculin allergy following 
lepromin injection; but in children it is not always possible to repeat the tests at as short intervals as they should be. This did not allow accurate determination of the length of the pre-allergic period between the injection of lepromin and the establishment of a positive Mantoux reaction, or of the duration of sensitiveness to tuberculin. In the majority of the cases in which the negative Mantoux became positive, it did so six to seven weeks after the intradermal injection of lepromin. The Mantoux again became negative after a few weeks, but it is not possible to state exactly when it did so. Possibly the number of cases showing a positive Mantoux following lepromin would have been greater if the tests had been carried out more often.

The standard for assessing results of tuberculin tests in work such as is here reported is of decisive importance, but sometimes of difficult application. If the usual standard for classifying erythema and infiltration as positive or negative is strictly adhered to, it is obvious that some reactions do not fulfil the conditions necessary to be considered as positive, yet are not exactly negative. It is certain that some change has been provoked in the organism, but this is not sufficient to be computed in the final result. In this series often the manner of response changed after lepromin injection, but the magnitude or intensity of this change was not sufficient to consider the reaction as positive. Attention should be drawn here to the fact that Long and Favour $(7)$ consider a tuberculin test as positive when there is some change in the response (erythema or infiltration), whatever its degree, at the site where the antigen has been inoculated.

It is possible that $M$. leprae can induce sensitiveness to tuberculin with greater frequency and intensity than has been observed in the series here reported, in which small quantities of dead bacilli have been used. If, instead, adequate amounts of live bacilli were inoculated, it is almost certain that the proportion of tuberculin positive reactions following inoculation would be greater than that observed after lepromin has been injected. This occurs when M. tuberculosis is inoculated; live bacilli (virulent or attenuated) have greater sensitizing activity than dead bacilli.

Owing to the deficiences of this investigation, striking results have not been obtained. It is possible to state, however, that following intradermal injection of whole lepromin, more than 40 per cent of tuberculin negative cases become tuberculin positive.

\section{SUMMARY}

A group of eighteen children, from 2 months to 8 years years old, living in a home without any known contact with lepers, 
having a Mantoux I : Io negative, was given I to 3 intradermic injection of 0.1 to 0.2 c.c. bacillary and/or whole lepromin. The following results were observed: in 44.4 per cent of the cases the negative Mantoux became positive in six to seven weeks following the injection of lepromin. The appearance and course of the positive tuberculin reaction was similar to that induced by BCG vaccination. In the majority of cases this tuberculin allergy was weak and of short duration.

\section{INFLUENCE OF LEPROMIN ON THE TUBERCULIN REACTION}

\begin{tabular}{|c|c|c|c|c|c|c|}
\hline Name & Age & $\begin{array}{l}\text { Lepromin } \\
\text { Used }\end{array}$ in & $\begin{array}{c}\text { No. of } \\
\text { injections }\end{array}$ & $\begin{array}{l}\text { Result } \\
\text { lepromin } \\
F^{*}\end{array}$ & $\begin{array}{l}\text { of the } \\
\text { reaction } \\
\text { M }\end{array}$ & $\begin{array}{l}\text { Result of } \\
\text { the Mantoux in } \\
\text { days after lepro. } \\
\text { min injection }\end{array}$ \\
\hline I-P.M. & 2 years & Whole & 2 & - & ++ & +130 \\
\hline $2-F \cdot M$. & 5 years & , & 3 & - & + & +20 \\
\hline 3-S.E. & 8 months & , & 2 & - & \pm & +40 \\
\hline 4-S.I. & 6 years & , & 3 & - & + & -240 \\
\hline 5-A.S. & I year & , & 2 & 一 & + & -90 \\
\hline 6-A.M. & 2 years & , & 2 & - & + & +42 \\
\hline 7 -L.A. & 5 months & , & I & - & 一 & - IOO \\
\hline 8-M.R. & $2 \mathrm{y} .6 \mathrm{~m}$. & .. & 2 & - & - & -90 \\
\hline $9-\mathrm{B} . \mathrm{J}$ & 2 years & , , & 2 & - & + & +42 \\
\hline Io-W.V. & 6 years & , & 2 & 一 & - & -90 \\
\hline I I-H.S. & 4 years & ., \& bac. & 2 & - & + & -90 \\
\hline I $2-\mathrm{S}$. & 6 years & ., $\quad$. & 2 & - & + & -90 \\
\hline I3-S. J. & 5 years & , & 2 & - & + & -47 \\
\hline I 4-H.M. & 6 years & , & 2 & - & + & -50 \\
\hline I 5-S.B. & 5 years & , & 2 & - & + & -90 \\
\hline I6-M.J. & & Bacillary & I & - & - & -90 \\
\hline I7-P.M. & & ,. & I & 一 & - & +47 \\
\hline I 8-D.S. & & ," & I & - & - & +47 \\
\hline I9-V.F. & ${ }^{*} \mathrm{~F}=1$ & reaction. & $\stackrel{\mathrm{I}}{\mathrm{M}}=\mathrm{D}$ & layed & $\stackrel{+}{\text { reaction. }}$ & -42 \\
\hline
\end{tabular}

\section{BIBLIOGRAPHY}

(1) WADE, H. W.-Reactions to tuberculin in leprosy. Inter. Jour. Lepr., 18, $1950,373$.

(2) Fernandez, J. M. M.-Relaciones inmuno alérgicas entre tuberculosis y lepra-III Congreso Arg. de Tisiología. Actas y Trabajos-Ed. Molachino, Rosario, 1952.

(3) Convir, J., Gonzalez, C. L. y Raissi, E.-Estudio sobre lepra en el grupo étnico alemán de la Calonia Tovar, Venezuela. Inter. Jour. Lepr., 20, $1952,185$.

(4) Convir, J. and RaIssi, E.-Lepromin and Tuberculin Tests in Venezuelan leprosy foci; induction of lepromin reactivity by BCG vaccination. Inter. Jour. Lepr., 22, 1954, 303.

(5) Lowe, J. and McNulTy, F.-Tuberculosis and Leprosy-Immunological Studies. Lepr. Rev., 24, 1953, 61.

(6) Hadler, W. A. and Zirti, L. M.-Estudo du sensibilidade tuberculinica em cobaios normais inoculados experimentalmente con " $M$. leprae," "M. lepraemurium" e "M. tuberculosis." Rev. Bras. Lepr., 21, 1953, 315.

(7) Long, J. B. and Favour, C. B.-The ability of ACTH and Cortisone to alter delayed type bacterial hypersensitivity. Bull. John Hopkins Hosp., $87,1950,186$ 